\section{EDITORIAL Inquéritos nacionais de saúde}

EDITORIAL

Este suplemento da Revista Brasileira de Epidemiologia apresenta resultados de dois importantes inquéritos nacionais de saúde, Vigilância dos Fatores de Risco e Proteção para Doenças Crônicas por Inquérito Telefônico (VIGITEL), e a I Pesquisa Nacional de Saúde do Escolar (PeNSE).

O VIGITEL foi implantado em 2006 nas 26 capitais brasileiras e no Distrito Federal. Foi coordenado pelo Ministério da Saúde, por intermédio da Secretaria de Vigilância em Saúde, com o apoio da Secretaria de Gestão Estratégica e Participativa e do Núcleo de Pesquisas Epidemiológicasem NutriçãoeSaúde(NUPENS) da Universidade de São Paulo. O VIGITEL tem contado também com o apoio do grupo técnico do Behavioral Risk Factor Surveillance System (BRFSS) do Centro de Controle de Doenças (CDC), dos Estados Unidos. Por meio de entrevistas telefônicas assistidas por computador, o VIGITEL utiliza-se de amostras probabilísticas da população adulta de 18 anos ou mais, residente em domicílios servidos por pelo menos uma linha telefônica fixa no ano da pesquisa, em cada uma das 26 capitais dos estados brasileiros e no Distrito Federal, totalizando mais de 54.000 entrevistas ao ano.

O VIGITEL permite ampliar o conhecimento do perfil epidemiológico da população adulta e fornece subsídios aos estados e municípios para o planejamento de ações de promoção de saúde, caracterizando-se como uma ferramenta de vigilância em saúde. Para cumprir esse objetivo, o VIGITEL deve ser um inquérito anual e contínuo para permitir análises de séries históricas dos indicadores de saúde, fundamental para a consolidação da Vigilância de Doenças e Agravos Não-transmissíveis no país.

Nessa publicação são apresentadas análises temporais dos principais indicadores monitoradospeloVIGITEL, demonstrandoastendências no que concerne à situação de saúde da população e aos principais fatores de risco para o desenvolvimento de doenças crônicas. Também são apresentados diferentes estudos comparativos entre o VIGITEL e inquéritos domiciliares, estudos de validação e análises dos módulos adicionais, subsidiando o planejamento de novos estudos e, principalmente, o aprimoramento do sistema. Em seu quinto ano de realização (2010),
National health surveys

The present issue of Brazilian Journal of Epidemiology comprises the results of two key national health surveys: Telephone-based Surveillance of Risk and Protective Factors for Chronic Diseases (VIGITEL) and National Survey of School Health (PeNSE).

VIGITEL was established in 2006 in all Brazilian state capitals and the Federal District, under the coordination of the Ministry of Health through the Health Surveillance Secretariat, and supported by the Center for Health and Nutrition Research (Núcleo de Pesquisas Epidemiológicas em Nutrição e Saúde - NUPENS) of Universidade de São Paulo (USP), and the Behavioral Risk Factor Surveillance System (BRFSS) of the Center for Disease Control (CDC). It consists of telephone interviews with adults (aged 18 years or more) living in all Brazilian state capitals and the Federal District who have a telephone landline. These criteria include over 54 thousand interviews per year.

Health surveys such as VIGITEL provide the officials with epidemiological information regarding the adult population, and enable the planning of health promotion actions; therefore, it is an important tool for health surveillance. To reach this goal, VIGITEL must be performed annually and gather data for further historical analysis of health indicators, which is essential to consolidate the surveillance and control of non-communicable diseases in the country.

This issue of RBE includes analyses of the main health indicators based on VIGITEL data, and portrays the trends in the population health and major risk factors for chronic diseases. It also has comparative studies involving VIGITEL and household surveys, as well as validation studies on new modules that provide background to further studies and the improvement of the system.

The fifth edition of VIGITEL (2010) included data on communicable diseases for the first time in order to meet the challenges imposed by the pandemic H1N1 in 2009. The most relevant results of this monitoring are also contemplated.

PeNSE was first performed in 2009 to monitor the population behavior with regard to chronic diseases and violence, being supported 
o VIGITEL incluiu, em seu módulo adicional, pela primeira vez, questões relativas às doenças transmissíveis, atendendo a uma demanda surgida com a emergência da pandemia de Influenza A H1N1, em 2009. Os principais resultados desse monitoramento estão descritos em um artigo específico desta publicação.

Em consonância com os objetivos de conhecer e monitorar os comportamentos em saúde da população brasileira, relacionados ao desenvolvimento de doenças crônicas e à ocorrência de violências e acidentes, a primeira PeNSE foi realizada em 2009, por meio da parceria entre o Ministério da Saúde e o Instituto Brasileiro de Geografia e Estatística (IBGE), com o suporte do Ministério da Educação. Ao estudar o modo de vida dos escolares do nono ano do Ensino Fundamental nas 26 capitais estaduais e do Distrito Federal, a PeNSE complementa as informações sobre os fatores de risco e proteção para doenças crônicas para essa faixa etária, constituindo assim a Vigilância de Doenças e Agravos Não-transmissíveis no Brasil.

A adolescência é uma fase de ganho de autonomia e transformações, que se refletem na adoção de novas práticas e atitudes e na exposição a diversas situações e riscos que podem comprometer a saúde presente e futura do jovem. Os estudos apresentados sobre o consumo de tabaco, álcool e outras drogas e o comportamento sexual dos estudantes mostram que conhecer a magnitude do problema é um passo fundamental para planejar intervenções e ações de promoção de saúde, especialmente no ambiente escolar.

Os artigos apresentados nesta publicação foram elaborados pela equipe da Secretaria de Vigilância em Saúde (MS) juntamente com diversas Instituições de Ensino e Pesquisa do país, a partir das análises de informações regulares e de qualidade geradas pelo Sistema Único de Saúde, trazendo reflexões sobre a atual situação das doenças e agravos não-transmissíveis na população brasileira e suas perspectivas. A divulgação dessas informações torna-se primordial para que sejam estabelecidas estratégias de enfrentamento dos principais riscos à saúde, por meio de políticas públicas de prevenção $\mathrm{e}$ promoção da saúde, além de contribuir para o fortalecimento do sistema de vigilância de doenças e agravos não-transmissíveis no país.

Jarbas Barbosa da Silva Jr. Vice-ministro de Vigilância em Saúde by the Ministry of Health, the Brazilian Institute of Geography and Statistics (IBGE), and the Ministry of Education.

This survey collects data on freshman scholars in the 26 state capitals and the Federal District, gathers information about risk and protective factors for chronic diseases in this age group, and takes part in the activities for the surveillance of non-communicable diseases and infections in Brazil.

Adolescenceisthephaseinwhichindividuals become autonomous and go through transformations that may lead them to adopt certain behaviors and attitudes or expose themselves to situations and risks that can cause health problems in the future. We present some studies on tobacco use and the consumption of alcohol and other drugs related to sexual behavior in this age group, which show the magnitude of the problem and the need for interventional actions - especially in the school environment.

All papers have been written by research institutions in association with the Ministry of Health. The information contained in each article was compiled from the records by the National Health System (SUS - Sistema Único de Saúde) and represents the current situation of the Brazilian Society as to non-communicable diseases and infections, as well as the perspectives. The full disclosure of these data is mandatory for the creation of public policies of health prevention and promotion that address the leading risks to health, and contributes with the improvement of our health surveillance system.

Jarbas Barbosa da Silva Jr. Vice-Minister of Health Surveillance 